\title{
POLITIK HUKUM ISLAM \\ DALAM SISTEM HUKUM TATA NEGARA REPUBLIK ISLAM IRAN
}

\author{
Undang Hidayat \\ Sekolah Tinggi Agama Islam al-Musadadiyyah Garut \\ E-Mail: undanghidayat@yahoo.com
}

\begin{abstract}
Iran is one of the Muslim countries with predominantly population which follow the Shiite ideology and system of government as well as representing prototife modern Islam. Imamate system applied in the constitutional system of the Islamic Republic of Iran represents a form of legal awareness and political will of the authorities to submit to Islamic legal doctrines. The most unique characteristic of the political development of Islamic law in Iran is political reform in the early days after the Islamic revolution, Ayatollah Khumayni perform as well as religious and political leaders. But in its development, religious leaders separated by political leaders. However, the fact that khumayni still the religious leaders and the president in the political perspective. Thus, all policies in the various State agencies in Republic Islam of Iran must be following to Khumayni.
\end{abstract}

\begin{abstract}
Abstrak
Iran adalah salah satu negara muslim dengan mayoritas penduduknya menganut faham Syi'ah dan sekaligus mewakili prototife sistem pemerintah Islam modern. Sistem imamah yang diaplikasikan dalam sistem ketatanegaraan Republik Islam Iran mewakili suatu bentuk kesadaran hukum dan kehendak politik penguasa untuk tunduk kepada doktrin hukum Islam. Karakteristik yang paling unik dari perkembangan politik hukum Islam di Iran adalah pada masa awal pembaharuan politik pasca gerakan revolusi Islam, Ayatullah Khumayni tampil sebagai pemimpin agama dan sekaligus pemimpin politik. Namun dalam perkembangannya pemimpin agama terpisah dengan pemimpin politik. Namun faktanya tidak ada apapun kehendak politik penguasa di berbagai badan Negara kecuali harus tunduk kepada Ayatullah.
\end{abstract}

Kata Kunci:

Politik Hukum Islam, Syi'ah, Marja’, dan Kekuasaan

\section{A. Pendahuluan}

Sejak beberapa dekade, Iran mewakili suatu bentuk ancaman Islam, dan tokoh kharismatik seperti Imam Ayatullah Khumayni merupakan lambang revolusi Islam yang hidup. Jika Khumayni menyebut Barat dan Amerika khususnya sebagai "Setan Besar", bagi banyak orang di Barat ia merupakan ulama abad pertengahan, ancaman bagi Timur Tengah dan Barat. Mulai dari pernyataanpernyataan Presiden sampai musik populer dan papan-papan nama, Imam Ayatullah Khumayni segera menjadi seseorang yang menyebabkan bangsa Amerika membencinya. ${ }^{1}$

Nampak sekali tercantum dalam Mukadimah Undang-Undang Dasar (UUD) Negara Republik Islam Iran, yang menyatakan bahwa sebagai pengungkap lembaga-lembaga kultural, sosial, politik, hukum dan ekonomi masyarakat Iran, didasarkan kepada prinsipprinsip dan presep-presep Islam yang merefleksikan aspirasi ummat Islam yang sebenarnya, diakomodasikan dalam suatu hakikat Revolusi Islam yang besar serta dalam arus perjuangan kaum muslimin yang sejak awal

1John L. Esposito, Ancaman Islam: Mitos atau Realitas (Mizan: Bandung. 1996), hlm. 113-114. 
permulaannya hingga tercapainya kemenangan itu terkristalisasi dalam slogan-slogan yang tegas dan menentukan dari keseluruhan berbagai kelompok rakyat. Sekarang pada saat menjelang pemenuhan agung dari kemenangan ini, kita berusaha untuk memenuhinya dengan segala wujud kita. ${ }^{2}$

Dari prolog tersebut, tampak jelas bahwa segala yang berkaitan dengan Iran hampir senantiasa direlasikan menjadi hierarki imamah dalam konstitusi Iran. Semangat keislaman menjadi nilai dasar idelogi yang kokoh menjadi simbol dari setiap perjuangan menuju keagungan Islam dan Iran dalam satu kesatuan. Tatkala para mullah membatasi diri dari urusan politik, justru yang tampil adalah sosok kepemimpinan cendekiawan yang memiliki keluhuran budi. Inilah Iran modern di bawah pimpinan Mahmoud Ahmadinejad.

\section{B. Politik Hukum Islam}

Politik hukum adalah aktivitas untuk menentukan suatu pilihan mengenai tujuan dan cara-cara yang hendak dipakai untuk mencapai tujuan hukum dalam masyarakat. Politik hukum dapat pula didefinisikan sebagai kebijaksanaan penyelenggara negara tentang apa yang dijadikan kriteria untuk menghukumkan sesuatu (menjadikan sesuatu sebagai hukum). Kebijaksanaan tersebut dapat berkaitan dengan pembentukan hukum dan penerapannya. $^{3}$

Kemudian dalam konteks pembaharuan dan politik hukum nasional, ${ }^{4}$ politik hukum merupakan suatu pernyataan kehendak penguasa negara mengenai hukum yang berlaku di wilayahnya, dan mengenai arah perkembangan hukum yang dibangun. Definisi yang sama juga menjelaskan bahwa politik hukum adalah kebijakan dari negara melalui

${ }^{2}$ Petikan dari Undang-Undang Dasar Republik Islam Iran (Jakarta: Kedutaan Besar Republik Islam Iran. t.th.), hlm. 1.

${ }^{3}$ Peneliti mengutip definisi politik hukum dari Satjipto Rahardjo dan Padmo Wahjono, Definisi Politik Hukum, yang diakses dari http://www.pengertiandefinisi.com/2012/01/pengertian-politik-hukum.html diakses tanggal 28 Desember 2012.

${ }^{4}$ Teuku Mohammad Radhie, Pembaharuan dan Politik Hukum dalam Rangka Pembangunan Nasional (Jakarta: Logos Wacana Ilmu. 1996), hlm. 3. badan-badan negara yang berwenang untuk menetapkan peraturan peraturan yang dikehendaki, yang diperkirakan akan digunakan untuk mengekspresikan apa yang terkandung dalam masyarakat dan untuk mencapai apa yang dicita-citakan. ${ }^{5}$

Berdasarkan beberapa pendapat para ahli di atas, maka secara operasional politik hukum ialah suatu pernyataan kehendak penguasa negara mengenai hukum mana yang diberlakukan di wilayahnya dan ke arah mana perkembangan hukum itu dibangun oleh badan-badan penyelenggara negara dalam berbagai bentuk peraturan perundang-undangan, sehingga terbentuk suatu kesadaran hukum dalam masyarakat untuk mencapai apa yang dicita-citakan.

Adapun hukum Islam adalah segala peraturan agama Islam yang meliputi semua aspek kehidupan manusia berupa akhlak, hukum-hukum ibadah, Kopercayaan dan keyakinan sebagai wujud aktualisasi sikap bathin seseorang yang beragama Islam. ${ }^{6}$ Dengan kata lain, makna integral syari'ah (hukum Islam) adalah keseluruhan peraturan Allah dan Rasul-Nya, baik dalam hubungannya antara manusia dengan Allah, dan manusia dengan manusia, serta manusia dengan makhluk hidup lainnya.?

Mengacu kepada beberapa definisi di atas, maka secara operasional yang dimaksud dengan dialektika politik hukum Islam menurut peneliti sendiri adalah perubahan cara pandang dan kesadaran hukum masyarakat secara terus-menerus secara triadik untuk menerima dan memberlakukan hukum Islam, serta kebijakan atau kehendak penguasa dalam menentukan arah hukum yang hendak dibangun dan diberlakukan di wilayahnya.

\section{Revolusi Islam Menuju Iran Modern}

Dalam prolog di atas, tersirat jelas bahwa revolusi Islam menjadi gaung perjuangan umat Islam di Iran yang senantiasa mengede-

${ }^{5}$ Soedarto, Politik Hukum di Indonesia (Jakarta: UI Press. 1995), hlm. 7.

${ }^{6}$ Yusuf Musa, Tarikh al-Fiqh al-Islami (Cairo Mesir: t.pn., t.th.), hlm. 10.

${ }^{7}$ Manna al-Qattan, al-Tasyri wa al-Fiqh fi al-Islam (t.t.: Muassasah al-Risalah. t.th.), hlm. 14. 
pankan Islam sebagai agama revolusi dan kesyahidan, dan sekaligus mempersatukan berbagai macam pandangan dan orientasi dalam tingkat wacana pemikiran dan interpretasi yang berbeda, yang kesemuanya diiringi dengan semangat idelogi Syi'ah dalam setiap gerakannya. $^{8}$

Sketsa historis menunjukkan suatu kebenaran opini di atas, dimana dalam republik Islam Iran, sejak berdirinya Dinasti Safawiyah (1501-1732 M), ketika Islam Syi'ah diproklamasikan sebagai agama negara, maka serta merta para Syah Iran mengklaim memerintah pada saat ghaibnya Imam yang kedua belas sejak tahun $874 \mathrm{M}$. Justru dalam keadaan inilah, mulai terjadi reposisi para ulama yang terkadang bersikap sebagai pendukung, tapi pada disisi lain juga sebagai oposisi. Sampai akhirnya, sepeninggal Dinasti Qajar (1794-1925 M), dan fakta terakhir Protes Tembakau (1891-1992 M) dan Revolusi Konstitusional tahun (1905-1919 M), Islam dan ulama menjalin suatu kontak yang mengarah kepada munculnya nasionalisme Islam modern untuk menghalau segala bentuk kolonialisme Barat yang anti Islam. ${ }^{9}$

Suatu hal yang menarik adalah manakala fakta historis yang menyajikan reposisi ulama naik ke panggung kekuasaan politik adalah ketika terjadinya revolusi Islam Iran yang menawarkan seperangkat lambang, identitas sejarah dan sistem nilai menjadi suatu alternatif non Barat, suatu kerangka ideologi dimana berbagai golongan dapat berfungsi. ${ }^{10}$ Jum'at Hitam 8 September 1978 merupakan realitas sejarah yang mengembalikan posisi ulama (para Imam) ke puncak kekuasaan. Melalui penyatuan kekusaan politik dan agama, membawa implikasi yang positif bagi perkembangan republik Islam Iran yang syarat dengan manifesto hegemoni ideologi Syi'ah yang meresap dalam aspek ideologi, sosial-budaya, politik dan hukum.

Keadaan yang demikian, membawa Iran kedalam supremasinya yang sangat spektakuler, terlebih lagi dikarenakan mereka sangat menjunjung tinggi prinsip Vilayat al-Faqih sebagai nilai paling fundamental dalam

\footnotetext{
${ }^{8}$ John L. Esposito, Ancaman Islam. hlm. 114.

${ }^{9} \mathrm{lbid} . \mathrm{hlm} .116$.

${ }^{10}$ Ibid. hlm. 122.
}

segala aspek kehidupan masyarakat dan negara Islam Iran. Untuk membuktikan pernyataan tersebut, peta perubahan politik dan hukum di Iran saat ini, masih tetap saja seperti Iran pada masa Khumayni. Kini, seorang Ahmadinejad pun menjadi satu dari sekian banyak Iranian yang tetap mempertahankan ideology politik yang dianutnya.

\section{Shi'isme: Potret Ideologi Politik Iran}

Di kalangan komunitas Syi'ah kontemporer tidak dikenal istilah pemisahan antara agama dan politik, baik dalam tataran konseptualnya maupun maupun prakteknya. Setiap bentuk kegiatan ritual keagamaan selalu dikaitkan dengan ritual politik. ${ }^{11}$ Dengan kata lain, hampir selalu ada dimensi sosio-politik dalam setiap upacara keagamaan, misalnya saja dalam ritus Shalat Jum'at yang hanya terpusat di Teheran, syarat sekali dengan "muatan politis".

Dalam perpektif Syi'ah, terdapat presiden jika politik diartikan suatu "perjuangan" atau "perlawanan" aktif dan kongkret terhadap suatu tatanan yang dinilai tidak adil, maka menjadi "benar" klaim yang menyatakan bahwa Syi'ah lebih bernuansa politis selain juga bernuansa ideologis, lebih daripada sunnisme. Karena fakta historis lebih memberi bukti akan kebenaran pendukung Syi'ah yang menganggap sebagai pengganti dan penerus risalah Islam yang dibawa oleh Rasulullah (dalam konteks Syi'ah Imamiyah). ${ }^{12}$

Fauzi M. Nazar dalam tulisannya tentang Demokrasi Dalam Filsafat Islam mengatakan bahwa "dalam teori politik Syi'ah menghapuskan sama sekali peran masyarakat atas dasar bahwa legislasi dan inspirasi ilahiyah akan menjadikan peran dan keputusan-keputusan yang diambil mereka itu

${ }^{11}$ S. Husein M. Jafri dalam bukunya Asal dan Sejarah Perkembangan Islam Syi'ah mengatakan bahwa: Pada dasarnya Islam bersifat religius, karena status yang diperoleh Muhammad sebagai Rasul Allah yang ditunjuk dan dikirim oleh Dia untuk menyampaikan Risalah-Nya kepada manusia, dan bersifat politis karena lingkungan dan keadaan tempat ia timbul dan tumbuh. Sebaliknya Syi'isme, dalam watak yang dibawanya, selalu bersifat religius dan politis, dan aspek-aspek ini ditemukan berdampingan sepanjang sejarahnya (Jakarta: Pustaka Hidayah. 1989), hlm. 26.

${ }^{12}$ Allamah Thabathaba'i, Islam Syi'ah (Bandung: Mizan. 1989), hlm. 88. 
mubadzir". ${ }^{13}$ Ini berarti segala otoritas politik maupun agama berpangkal pada eksistensi Imam yang memiliki peran ganda dalam membimbing umat Islam menuju risalah Islam yang dikehendaki.

Konteks yang ada dalam negara republik Islam Iran begitu kental dengan konsep Imamahnya, yang mencerminkan suatu bentuk otoritas politik dan agama ada pada tangan Imam. ${ }^{14}$ Inilah yang lebih identik dengan sekte Syi'ah Imamiyah yang meyakini keadaan Imam diambil secara hierarchies berdasarkan garis silsilah keluarga (family line age), khususnya keluarga Nabi (ahl al-Bait) yang berasal dari suku Quraisy, dan lebih khusus lagi Bani Hasyim. ${ }^{15}$

Diyakini oleh para pengikut Syi'ah, bahwa Imam terakhir (al-Mahdi) mengalami apa yang disebut "ghaib sempurna" pada tahun $941 \mathrm{M}$, dan diyakini pula akan datang kembali pada saatnya nanti. ${ }^{16}$ Dikalangan Syi'ah keyakinan ini masih tetap hidup dan menjadi pemegang kekuasaan yang sah. Karenanya, ketika kehadiran Imam terakhir tidak juga muncul diupayakan melalui suatu konteks pemeliharaan otoritas politik dan agama tersebut dalam terma Vilayat al-Faqih. ${ }^{17}$ Hanya saja, jika boleh berandai-andai, akan bagaimana sikap dan keadaan para pengikut kalangan Syi'ah Imamiyah, jika imam terakhir tersebut benar-benar muncul, sekalipun rentang waktu yang lama dimasa lalu memberi indikasi yang menunjukkan suatu kemuskilan dan absurd.

Gambaran sejarah politik Islam di Iran, telah mengalami paruh waktu perkembangannya yang sangat dinamistik. Terutama ketika pada tahun 1970-an Syah Iran sudah

${ }^{13}$ Fauzi M.Nazar, Demokrasi dalam Filsafat Islam, Al-Hikmah : Jurnal Studi-Studi Islam No.2, Juli-Oktober 1990, hlm. 82 dan Hamid Enayat dalam Reaksi Politik Sunni dan Syi'ah (Bandung: Pustaka. 1988), hlm. 7-8.

${ }^{14}$ Abdul Aziz Sachedina, Kepemimpinan dalam Islam (Bandung: Mizan. 1991), hlm. 153.

${ }^{15}$ Allamah Thabathaba'i, Islam Syi'ah. hlm. 89. Dan kutipan Riza Sihbudi dari Mehdi Mozaffari dalam Authorithy in Islam : From Muhammad to Khomeini (London: M.E. Sharpe. 1987), hlm. 36.

${ }^{16}$ Riza Sihbudi, Tinjauan Teoritis dan Praktis Atas Konsep Vilayat-i Faqih : Sebuah Pengantar (t.t.: Ulumul Quran. 1993), vol. IV, hlm. 74.

${ }^{17}$ Ibid. hlm. 74-75. bukan lagi merupakan simbol kekuasaan. Para pembaharu Iran, kelompok oposisi, menunjukkan suatu contoh yang refresentatif bagi keselurahan golongan masyarakat Islam di Iran yang nasionalis dan sayap kiri, sekuler dan agama, kaum elite tradisional dan elite modern. ${ }^{18}$ Ketergantungan Iran pada masa syah Reza Pahlevi sebelumnya yang cenderung tergantung kepada Barat, telah memicu kalangan pembaharu seperti Jalali Ahmad, Mahdi Bazarqan, Ali Syari'ati dan Ayatullah Khumayni, untuk melakukan gerakan revolusi dan modernisasi Islam Iran, yang sekarang kemudian berhasil membawa Iran menjadi negara republik Islam yang diperhitungkan dan ditakuti oleh Barat. ${ }^{19}$

Sejak berdirinya Republik Islam Iran, telah memunculkan suatu babak baru perjuangan antara kelompok moderat dan militan, dimana kewenangan Syah dan Elite Sekuler modernanya ditumbangkan oleh kewenangan Imam sebagai wali dan faqihnya pengikutnya. ${ }^{20}$ Namun dalam perkembangan selanjutnya, muncul berbagai infiltrasi politik antara kalangan ulama, seperti kasus mundurnya Mahdi Bazarqan dari kursi Perdana Menteri, Sadeq Gobtzadeh (Presiden terpilih) yang lari ke Perancis, telah terjebak pada rencana maut pembunuhan atas Ayatullah Khumayni yang sekaligus pula sebagai gurunya. Ketidaktegasan Ayatullah Syariat madari (Ayatullah Senior) digulingkan oleh kalangan Ayatullah lainnya. Sehingga membuat Khumayni harus mengkonsolidasikan ulama (Ayatullah dan para Mullah) untuk mengontrol setiap lembaga pemerintahan baik sipil maupun militer serta agama maupun politik ${ }^{21}$.

Karena keadaan tersebut, Iran selamat dari disintegrasi dan kembali ke dalam kesatuan umat dalam kekuasaan Imamah. Satu babak baru pembagian kekuasaan dalam politik Islam Iran adalah adanya pemimpin politik dan pemimpin spiritual, yakni ketika Ayatullah Khumayni meninggal dunia, tidak terjadi perebutan kekuasaan, melainkan dibagi menjadi dua, yakni Dewan Wakil Rakyat me-

\footnotetext{
${ }^{18}$ John L. Esposito, Ancaman Islam. hlm. 117.

${ }^{19}$ lbid. hlm. 116-118.

${ }^{20} \mathrm{Ibid}$. hlm. 124-125.

${ }^{21}$ Ibid. hlm. 126-127.
} 
milih Hashemi Rafsanjani sebagai Presiden dan Dewan Ahli memilih Ayatullah Khameini sebagai pemegang peran utama (Wali Faqih Iran).

Bahkan, hampir dapat dipastikan ketika arus modernisasi kini melanda Iran seperti sekarang ini, Mahmoud Ahmadinejad tetap meneruskan kebijakan para pendahulunya. Iran di bawah pimpinan Ahmadinejad tetap menjadi "setan yang menakutkan" bagi Barat, khususnya Amerika Serikat. Iran seringkali dituduh menjadi negara Muslim sponsor terorisme. Padahal tuduhan Barat (AS dan Inggris) semata-mata berdasar pada ketakutan mereka atas menguatnya posisi tawar politik Iran di kancah internasional di bawah kepemimpinan presiden Mahmoud Ahmadinejad.

\section{E. Prinsip Imamah: Landasan Vilayat al- Faqih}

Perkembangan pemikiran politik hukum Syi'ah dalam masalah Imamah (kepemimpinan) dapat dibagi menjadi dua tahap. Pertama, pemikiran Syi'ah ketika para imam mereka masih hidup. Kedua, pemikiran Syi'ah yang berlangsung setelah ghaibnya imam alMahdi. ${ }^{22}$ Seperti halnya dikutip oleh Riza Sihbudi (seorang pengamat politik timur tengah) dari tulisan Sachedina tentang perkembangan sikap politik kaum Syi'ah Imamiyah mengandung tiga instrumen pokok, yaitu: Syahadah (kesyahidan/martydrom), keghaiban (Ghaybah/Occultation) dan Taqiyyah (dissi mulation/penyembunyian kebenaran demi kewaspadaan dan mencegah kesia-siaan). ${ }^{23}$

Lebih lanjut, dikatakan bahwa keghaiban terbagi dua tingkatan: Pertama, masa keghaiban kecil (minor occulation/ghaybah alSughra) yaitu ketika Imam Mahdi bersembunyi di dunia fisik dan mewakilkan kepemimpinannya kepada para wakil Imam. ${ }^{24} \mathrm{~Pa}-$ da masa ini terjadi kesulitan dalam hal marja (kepemimpinan agama dan politik), relatif dapat diatasi karena ada empat orang wakil

${ }^{22}$ Jalaludin Rachmat, Kepemimpinan Dalam Perspektif Syi'ah, Makalah dalam Diskusi Buku di IAIN SGD Bandung, tanggal 9 Mei 1992.

${ }^{23}$ Riza Sihbudi, Tinjauan Teoritis. hlm. 74.

${ }^{24}$ Jalaludin Rachmat, Kepemimpinan Dalam. hlm. 255.
al-Mahdi (Abu 'Amr bin Uthman, Abu Ja'far Muhammad, Abu al-Qasim al-Hussayn dan Abu al-Hasan 'Ali). ${ }^{25}$

Kedua, masa keghaiban besar (major occulation/ghaybah al-Kubra) yaitu masa sesudah meninggalnya empat wakil imam yang kemudian dilanjutkan oleh para faqih. Jadi, dalam hal ini para Imam memiliki kewajiban untuk meneruskan risalah Nabi dalam siklus Imamah. Sedangkan Imamah itu sendiri menjadi landasan utama prinsip Vilayat al-Faqih. Prinsip Vilayat al-Faqih yang dikehendaki mencakup tiga pangkal ${ }^{26}$, yaitu :

1. Dasar-dasar Vilayat al-Faqih, antara lain:

a. Aturan Islam yang menggariskan semua aktivitas manusia, dari dalam secara intelektual dan visi;

b. Putusan pemikiran yang bebas dan opini-opini yang bijak, sepanjang sejarah kehidupan peradaban, perlunya keberadaan otoritas dan penguasa masyarakat;

c. Perlunya mengurusi persoalan-persoalan dalam pemerintahan;

d. Adanya para ulama sebagai wakil para nabi;

e. Otoritas imam dalam menyelesaikan perselisihan;

f. Dasar pandangan wasiat Nabi yang mengharuskan adanya penerus risalahnya; dan

g. Adanya perwalian dan pemerintahan dalam negara.

2. Syarat-syarat yang harus dipenuhi, antara lain :

a. Ijtihad, keahlian dalam Yurisprudensi Islam;

b. Keadilan dan ketaqwaan; dan

c. Wawasan Sosial dan Politik.

3. Lingkup dan batasan Vilayat al-Faqih, antara lain:

a. Mengurus berbagai urusan kehidupan umat;

b. Mengurus berbagai urusan pemerintahan dan Negara;

Pemaknaan tentang Vilayat al-Faqih sebenarnya lebih menjiwai dalam realitas po-

\footnotetext{
${ }^{25}$ Mozaffari, Authorithy in Islam: From Muhammad to Khumayni (London: M.E. Sharpe. 1987), hlm. 38.

${ }^{26}$ Ali Mishkini, Wilayah Faqih: Ulama Pewaris Kenabian, Risalah Masa (Jakarta: t.pn. 1991), hlm. 44-61.
} 
litik Syi'ah Imamiyah di Iran, maka tidak heran kemudian terjadi akumulasi penyatuan konteks politik dan agama dalam kehidupan. Dengan kata lain, reposisi ulama dalam realitas sosial dan politik seharusnya diletakkan kepada konsep na'ib al-'amm pada konsekuensinya hak para fakih yang sekaligus kedudukan sebagai wakil Imam harus menyentuh aspek keagamaan, sosial dan politik sebagai instrumen dalam Vilayat al-Faqih. ${ }^{27}$ Semangat ini tidak hanya dalam bidang politik dan keagamaan, tetapi juga dalam bidang hukum.

Dalam konteks pemerintahan Islam, sekurang-kurangnya ada delapan persya-ratan yang harus dipenuhi oleh seorang faqih, yaitu : ${ }^{28}$

1. Mempunyai pengetahuan yang luas tentang hukum Islam;

2. Adil disertai iman dan akhlak yang mulia.

3. Dipercaya dan berbudi luhur;

4. Jenius dan brilian;

5. Memiliki kemampuan administratif;

6. Bebas dari segala pengaruh asing;

7. Mampu mempertahankan atas hak-hak bangsa, kemerdekaan dan integritas teritorial tanah Islam, sekalipun harus dibayar dengan nyawa;

8. Hidup sederhana.

Adapun tujuan dan misi pemerintahan Islam, memiliki tugas dan fungsi sebagai berikut:

1. Mempertahankan lembaga dan hukum Islam;

2. Melaksanakan hukum Islam;

3. Membangun tatanan yang adil;

4. Memungut dan memanfaatkan pajak sesuai dengan ajaran Islam;

5. Menentang segala bentuk agresi, mempertahankan kemerdekaan dan integritas teritorial tanah Islam;

6. Memajukan pendidikan;

\footnotetext{
${ }^{27}$ Riza Sihbudi, Tinjauan Teoritis. hlm. 76.

${ }^{28} \mathrm{lbid}$. hlm. 78-79. Mengutip pendapat Ayatullah Rahullah Khomeini dalam Sebuah Pandanagan Tentang Pemerintahan Islam: Dalam Beberapa Pandangan Tentang Pemerintahan Islam, Ed. Salim Azam (Bandung: Mizan. 1983), hlm. 130. Ayatullah Khomeyni dalam Islamic Government (Roma: European Islamic Culture. 1985), hlm. 52-53. dan Najibullah Laffraire dalam Ideologi of revolution, Desertasi Doktor pada Hawaii University, hlm. 158-185.
}

7. Memberantas korupsi dan segala jenis penyakit sosial lainnya;

8. Memberikan perlakuan yang sama kepada semua warga negara tanpa diskriminasi;

9. Memecahkan masalah kemiskinan; dan

10. Memberikan pelayanan kemanusiaan secara umum.

Konsep Vilayat al-Faqih tersebut, merupakan suatu bagian yang tercantum dalam konstitusi negara Republik Islam Iran. Seperti dicantumkan dalam Undang-Undang Dasar Republik Islam Iran dikatakan dalam Pasal 107 konstitusi 1979 disebutkan pada prinsipnya mensyahkan Ayatullah Khumayni sebagai Vilayat al-faqih, Marja' Taqlid yang terkemuka dan sekaligus sebagai pemimpin revolusi Islam Iran. ${ }^{29}$

Begitu besarnya pengaruh pemikiran para ulama di Iran yang dimotori oleh Imam Ayatullah Khumayni pasca Revolusi Islam Iran, semakin memperdalam de-Islamisasi Iran dalam segala lapangan kehidupan, khususnya pranata-pranata politik Islam. Hampir kesemuanya mengalami suatu bentuk simbolisasi dalam naungan pengaruh besarnya ajaran Syi'ah Imamiyah di negara tersebut.

Transmisi kekuasaan politik Islam menurut Syi'ah Imamiyah, yang dimplementasikan dalam konteks negara Republik Islam Iran, dapat dilihat dalam gambar di bawah ini:

\footnotetext{
${ }^{29}$ Undang-undang Dasar Republik Islam Iran (Jakarta: Kedutaan Besar Republik Islam Iran. t.th.), hlm. 67.
} 


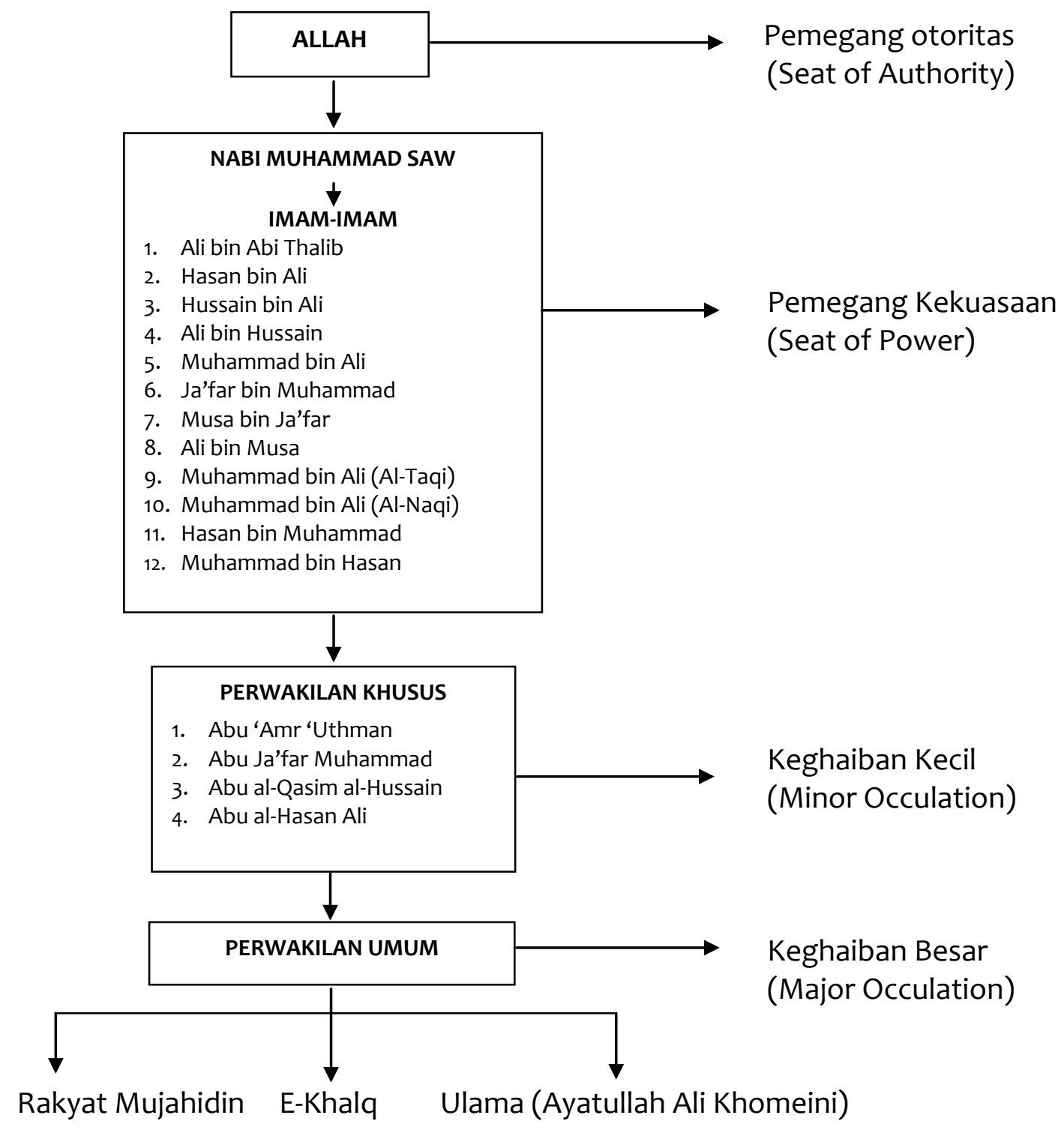

\section{F. Potret Politik Hukum Islam di Iran}

Keyakinan untuk membentuk suatu tatanan politik Islam yang paling tangguh, telah dicermati oleh Ayatullah Khumayni melalui Vilayat al-Fiqih-nya. Seperti juga pada umumnya negara modern yang menganut sistem pembagian kekuasaan menjadi tiga bentuk yakni kekuasaan eksekutif, legislatif dan Yudikatif. Iran menerapkan konsep Vilayat al-Faqih dalam struktur politik pemerintahan dan negaranya. Karena dalam konstitusi Iran disebutkan bahwa pemerintahan merupakan suatu kristalisasi dari ideal-ideal politik, dari rakyat yang seagama dan sepikiran mengorganisasikan diri supaya dalam proses perubahan pikiran dan kepercayaan- kepercayaan, ia membuka jalan menuju ke arah tujuan terakhir, yang bergerak menuju Tuhan $^{30}$.

Upaya-upaya ke arah pembaharuan dan modernisasi politik dan hukum di Iran, juga ditempuh dalam bentuk amandement konstitusi negara Republik Islam Iran yang dilakukan oleh Majlis Mu'assisan (Majelis Konstituante) yang dibentuk berdasarkan Dekrit Ayatullah Khumayni. Majlis ini kemudian berubah menjadi Majlis Khubregan (Majlis Ahli) yang dipilih oleh rakyat untuk memilih pemimpin negara yang didalamnya juga mene-

${ }^{30}$ Ibid. hlm. 9 . 
rapkan konsep Vilayat al-Faqih dalam setiap pranata politik yang ada.

Untuk mengenal lebih jauh tentang, politik hukum Islam di Iran dapat diketahui dalam sketsa yang menggambarkan struktur dan pranata-pranata politik Islam di Iran pasca Revolusi Islam Iran tahun 1979 dan setelah terjadi amandement konstitusi Republik Islam Iran. ${ }^{31}$ Amandemen yang telah dilakukan oleh pemerintahan Islam Iran dilakukan untuk merespon semua perkembangan kemajuan zaman yang semakin syarat dengan tuntutan realitas sosial-budaya dan politiknya. la sangat membutuhkan kesiapan bagi terjaminnya keutuhan stabilitas ideologi dan politik Islam Syi'ah di Iran pada khusunya dan di Arab-Asia Selatan pada umumnya. Karena Timur Tengah, walau bagaimanapun merupakan lahan yang selama ini dijadikan sasaran untuk menjadi bagian dari propaganda Barat yang hendak menyerang Islam di segala bidang.
Perkembangan paling mutakhir, perubahan politik hukum Islam di Iran setelah era Khumayni adalah ditunjuknya Ayatullah Ali Khumayni sebagai pemimpin spiritual Iran. Sedangkan perubahan struktur dan pranatapranata politik Islam di Iran pasca wafatnya Imam Khumayni diteruskan melalui pemilu untuk memilih anggota parlemen secara demokratis. Sesuai dengan hasil amandemen konstitusi sebelumnya, Mahmoud Ahmadinejad berhasil terpilih sebagai Presiden Republik Islam Iran. Di bawah kepemimpinan Ahmadinejad, Iran memasuki babak baru yakni terjaminnya demokratisasi di bidang politik, hukum, ekonomi, sosial dan budaya. Bahkan Iran disinyalir telah berhasil mengembang rudal berhulu ledak nuklir dengan daya jelajah yang sanggup mencapai tiga perempat daratan dunia. Maka tidak heran, Iran menjadi hantu menakutkan bagi Amerika Serikat dan Inggris, serta negara-negara di kawasan Eropa Barat.

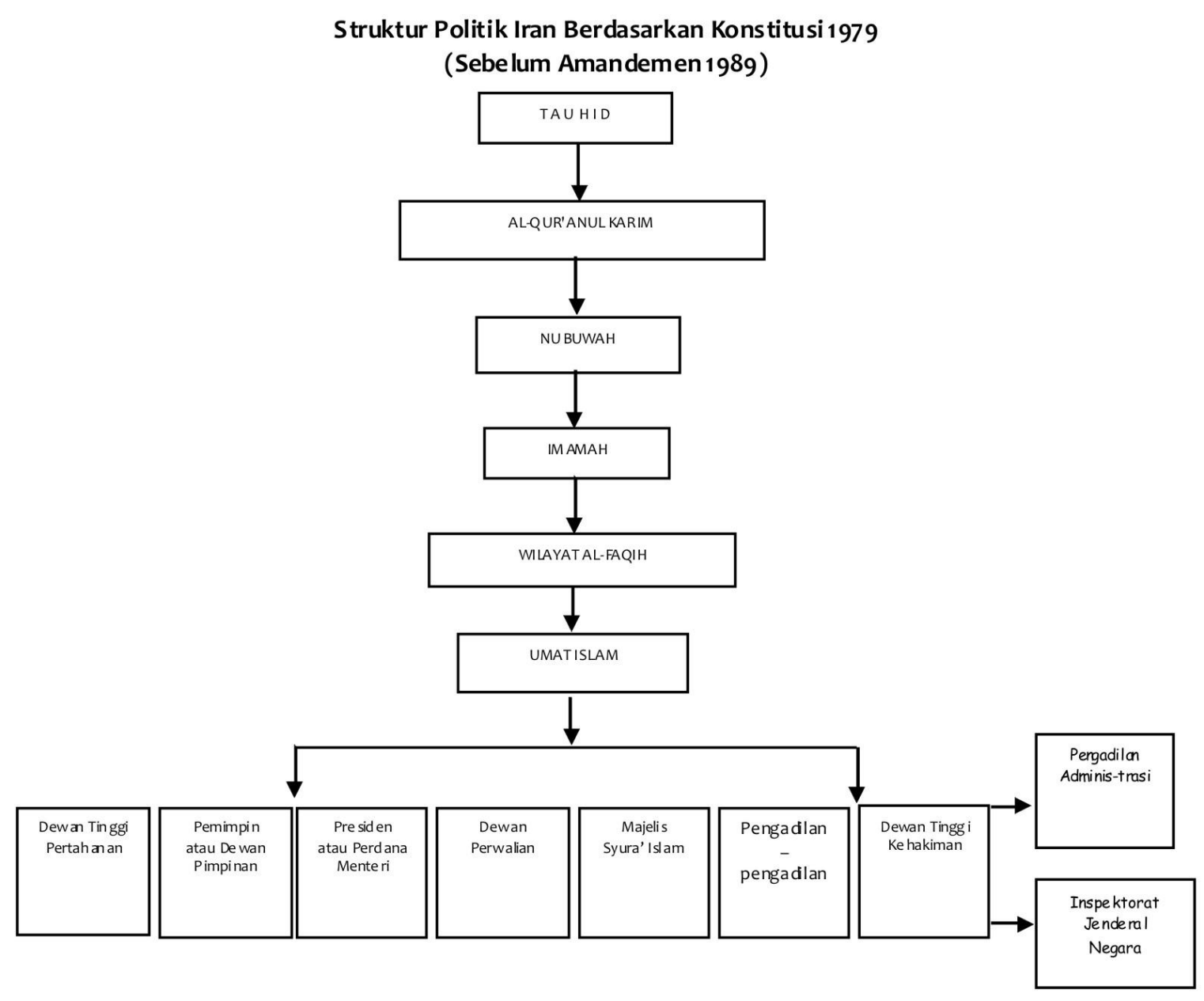

${ }^{31}$ Ibid. hal. 81-82. 


\section{Struktur Politik Iran Berdasarkan Konstitusi 1979} (Setelah Amandemen 1989)

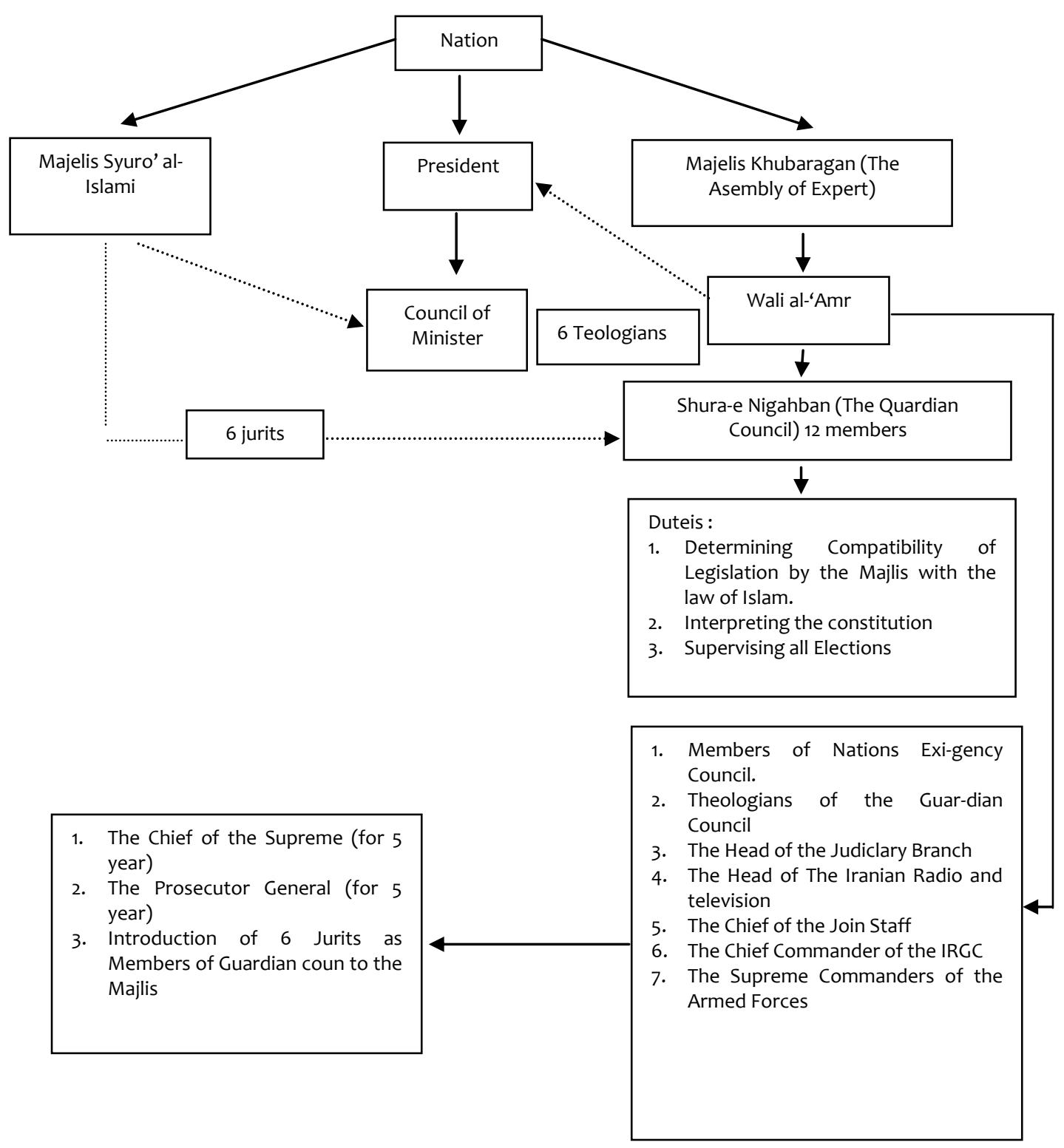

Member of the Supreme Council for National Scurity :

1. Head the Three Branches of the governement

2. Chief of the Supreme Command Council of the Armed Forces

3. The officer Incharge of the Planning and Budget Affairs

4. Two Refresentatives nominater by the leader

5. Minister of foreign affairs, interior and information

6. Related with the Subject the minister and the highest rangking officials from the Armed forces and the IRGC.

\section{G. Penutup}

Iran yang dalam masa dahulunya merupakan wilayah Islam yang sangat nampak kemajuan peradabannya, terutama setelah berbaurnya pemikiran Islam di negara tersebut, ternyata memiliki suatu identitas tersendiri yang tidak dimiliki oleh sebagian besar dunia Islam lainnya. Corak perbedaan pemikiran ideologi politik dan hukum di negara terse- 
but sangat kental dengan warna Syi'ah Imamiyah.

Kondisi dinamistik yang terjadi dikalangan ulama dan pemikir Islam Iran, baik pada masa klasik, pertengahan maupun modern juga telah membawa Iran ke dalam suatu tatanan politik yang kuat dan tangguh dibawah kendali keseimbangan antara agama dan politik, yang dipengaruhi oleh konsep Vilayat al-Faqih dalam Syi'ah Imamiyah. Maka dalam konteks yang seharusnya, Iran memiliki peluang yang lebih terbuka, ketika persoalan perbedaan faham Sunni-Syi'ah tidak lagi dijadikan instrumen perpecahan dikalangan umat Islam.

Perkembangan politik hukum Islam yang ada di Iran jelas merupakan realitas kemandirian kalangan Syi'ah Imamiyah modern yang selama ini dianggap telah mampu membangun suatu tatanan masyarakat negara hukum modern yang sebelumnya dianggap statis menjadi dinamis, yang semula hanya merupakan cita-cita, namun kini menjadi kenyataan di mana setiap orang Iran tidak dapat menafikannya dirinya sebagai warga negara Republik Islam yang modern di kawasan Timur Tengah.

\section{Daftar Pustaka}

Enayat, Hamid. 1988. Reaksi Politik Sunni dan Syi'ah. Bandung: Pustaka.

Esposito, John L. 1996. Ancaman Islam : Mitos atau Realitas. Mizan: Bandung.

http://www.pengertiandefinisi.com/2012/01/p engertian-politik-hukum.html diakses tanggal 28 Desember 2012.
Rachmat, Jalaludin. Kepemimpinan Dalam Perspektif Syi'ah, Makalah dalam Diskusi Buku di IAIN SGD Bandung, tanggal 9 Mei 1992.

M. Jafri, S. Husein. 1989. Asal dan Sejarah Perkembangan Islam Syi'ah. Jakarta: Pustaka Hidayah.

M. Nazar, Fauzi. Demokrasi Dalam Filsafat Islam, Al-Hikmah: Jurnal Studi-Studi Islam No.2, Juli-Oktober 1990.

Mishkini, Ali. 1991. Wilayah Faqih: Ulama Pewaris Kenabian, Risalah Masa Jakarta: t.pn.)

Mohammad Radhie, Teuku. 1996. Pembaharuan dan Politik Hukum dalam Rangka Pembangunan Nasional. Jakarta: Logos Wacana Ilmu.

Mozaffari, Mehdi. 1987. Authorithy in Islam: From Muhammad to Khumayni London: M.E. Sharpe.

Musa, Yusuf. t.th. Tarikh al-Figh al-Islami. Cairo Mesir: t.pn.

Qattan, Manna, al-. t.th. al-Tasyri wa al-Figh fi al-Islam. t.t.: Muassasah al-Risalah.

Sachedina, Abdul Aziz. 1991. Kepemimpinan Dalam Islam. Bandung: Mizan.

Sihbudi, Riza. t.th. Tinjauan Teoritis dan Praktis Atas Konsep Vilayat-i Faqih: Sebuah Pengantar. t.t.: Ulumul Qur'an.

Soedarto. 1995. Politik Hukum di Indonesia. Jakarta: UI Press.

Thabathaba'i, Allamah. 1989. Islam Syi'ah. Bandung: Mizan.

Undang-Undang Dasar Republik Islam Iran. Jakarta: Kedutaan Besar Republik Islam Iran. 